\title{
APLIKASI ULTRASOUND ASSISTED EXTRACTION UNTUK PRODUKSI MINYAK BAWANG PUTIH VARIETAS LOKAL
}

\author{
Ultrasound Assisted Extraction Application for \\ Producing Local Variety Garlic Essential Oil
}

\author{
Kurniawan Yuniarto ${ }^{1 *}$, Cahyo Mustiko Okta Muvianto ${ }^{2}$ Ernia $^{3}$ \\ 1,3 Program Studi Teknik Pertanian - Fakultas Teknologi Pangan dan Agroindustri \\ Universitas Mataram \\ 2Jurusan Teknik Elektro - Fakultas Teknik - Universitas Mataram \\ Jl. Majapahit 62, Mataram 83125 \\ *Penulis Korespondensi, email : kurniawan2006@unram.ac.id
}

Disubmit : 7 Februari 2021 Direvisi : 12 Agustus $2021 \quad$ Diterima : 24 November 2021

\begin{abstract}
ABSTRAK
Operasi ekstraksi bahan hasil pertanian melibatkan proses pelepasan bahan aktif dari dalam jaringan tanaman. Teknik ekstraksi komponen bioaktif menggunakan ultrasonik atau ultrasound assisted extraction (UAE) menjadi salah satu metode yang mulai diminati karena efek dari kavitasi yang ditimbulkan dapat mendukung efisiensi waktu, penggunaan pelarut lebih sedikit dan tidak invasif. Penelitian ini memanfaatkan gelombang ultrasonik dengan frekuensi $37 \mathrm{kHz}$ untuk ekstrasi minyak bawang varietas lokal jenis Bagong, Tunggal dan Sangga. Pengeringan awal irisan bawang putih dengan suhu $60{ }^{\circ} \mathrm{C}$ selama 6 jam diterapkan untuk mengurangi kadar air awal. Selanjutnya, UAE diterapkan untuk ekstrak irisan bawang putih dengan variabel waktu ekstraksi terdiri atas 20 menit, 30 menit, dan 45 menit. Ekstrak kasar disaring dan diuapkan menggunakan vacuum evaporator suhu $60{ }^{\circ} \mathrm{C}$ selama 15 menit. Selanjutnya, minyak bawang putih di sentrifus dengan kecepatan 3000 rpm selama 15 menit untuk memisahkan partikel terlarut. Hasil penelitian di peroleh rendemen tertinggi di peroleh dari jenis bawang putih Sangga dan waktu ekstraksi 45 menit dengan hasil rendemen sebesar $12,35 \%$. Nilai indeks bias tidak menunjukkan perbedaan yang nyata pada perlakuan jenis bawang putih maupun lama pemberian gelombang ultrasonik dalam rentang 20 sampai 45 menit dengan nilai indeks bias sebesar 1,3678-1,3741. Hasil pengukuran GCMS menunjukkan kandungan komponen allyl trisulfida paling tinggi pada varietas bawang Putih Tunggal sebesar $11,19 \%$. Selanjutnya, aktivitas antioksidan akan semakin besar pada minyak atsiri yang terekstrak dengan periode UAE semakin panjang dengan nilai aktivitas antioksidan paling tinggi pada jenis bawang putih Sangga dengan lama ekstraksi 45 menit.
\end{abstract}

Kata kunci: Bawang Putih; Bioaktif; Ekstraksi; Kavitasi; Minyak

\section{ABSTRACT}

Extraction of agricultural products involves bioactive compound release within plant cellular. Recently, ultrasound-assisted extraction (UAE) has been developed as an extraction technique due to the cavitation effect that implies processing efficiencies such as time requirement, solvent use and noninvasive. This research applied ultrasonic wave at $37 \mathrm{kHZ}$ frequency to encourage essential oil of local garlic: Tunggal, Bagong and Sangga. Garlic chip was predried in the dryer at $60^{\circ} \mathrm{C}$ for 6 hours to reduce initial moisture content. The UAE used time variable into three levels i.e $20 \mathrm{~min}, 30 \mathrm{~min}$, and $45 \mathrm{~min}$ and was applying $90 \%$ pro analyst ethanol solvent. The crude garlic essential oil extract was filtered and 
Jurnal Teknologi Pertanian Vol. 22 No. 3 [Desember 2021] 177-186

Aplikasi Ultrasound Assisted Extraction untuk Produksi Minyak Bawang Putih Varietas Lokal

[Yuniarto dkk]

evaporated using a vacuum evaporator at $60^{\circ} \mathrm{C}$ for $15 \mathrm{~min}$. Then, centrifugation was proceeded at 3000 rpm for 15 min to produce pure garlic essential oil. This research resulted that Sangga garlic producing a higher essential oil yield than Tunggal and Bagong garlic where the highest yield was 12.35\% for $45 \mathrm{~min}$ time extraction. The oil essential did not show any different result of the oil refractive index parameter where the refractive index was measured between 1.3678 and 1.3741. The GC-MS observed allyl trisulfide compound in all of the local garlic and Tunggal garlic was the largest at about $11.19 \%$. Furthermore, the antioxidant activity will be greater in essential oils extracted with a longer UAE period with the highest antioxidant activity value in Sangga garlic with 45 minutes of extraction time.

Keywords: Bioactive; Cavitation; Essential, Extraction; Garlic

\section{PENDAHULUAN}

Ekstraksi adalah teknik pemisahan senyawa berdasarkan perbedaan distribusi zat terlarut di antara 2 pelarut yang saling bercampur. Proses ekstraksi bertujuan untuk mendapatkan komponen-komponen tertentu seperti bioaktif dari suatu tanaman tertentu. Beberapa metode ekstraksi yang sudah sering dilakukan, yaitu ekstraksi dengan pelarut (maserasi), destilasi, ekstraksi fluida super kritis, pengepresan mekanik dan sublimasi, serta secara enzimatik (Sulaswatty, 2019).

Perkembangan teknik ekstraksi bahan hasil pertanian menuntut adanya pemanfaatan metode yang lebih efisien terhadap waktu, mendukung hasil rendemen lebih tinggi, aman terhadap lingkungan dan sedikit menggunakan bahan palarut (Tiwari, 2015). Ultrasonic-assisted extraction (UAE) sendiri adalah salah satu metode ekstraksi berbasis gelombang ultrasonik yang mulai banyak diminati dalam perkembangan teknologi ekstraksi untuk bahan hasil pertanian dan proses kimia. Penggunaan gelombang ultrasonik memiliki sifat proses non-destructive dan non-invasive sehingga dapat dengan mudah diadaptasikan ke berbagai aplikasi (Mason et al., 2015).

Energi listrik dari daya yang dibangkitkan ultrasonik dirubah menjadi energi mekanik dalam bentuk osilasi dan dirubah lagi menjai energi akustik dalam bentuk gelombang ultrasonik menembus media menyebabkan osilasi (Löning et al., 2002). Selanjutnya, perubahan energi ini akan menyebabkan terjadi laju perubahan suhu (Kobus dan Kusinska, 2008). Analisis energi selama perlakuan "high-power ultrasonik" diikuti oleh fenomena konduksi menyebabkan adanya perpindahan panas (Hoffmann et al., 1996), efek kavitasi menyebarkan energi secara merata di dalam media (Son et al., 2012) dan keseragaman suhu tercapai setelah gelembung pecah (Hoffmann et al., 1996). Kenaikan suhu dipengaruhi oleh beberapa faktor seperti, kavitasi akustik, pembentukan gelembung dan sedikit disipasi panas selama proses sonikasi sehingga tercapai tahap suhu kesetimbangan antara pembuangan panas media dan daya serap (Wagh et al., 2016). Cara ekstraksi ini biasanya lebih cepat dan lebih efisien dibandingkan dengan cara-cara ekstraksi terdahulu (Cravotto dan Cintas, 2006).

Studi mengenai penggunaan gelombang ultrasonik juga dilaporkan oleh para peneliti lain. Ultrasonic-assisted extraction (UAE) untuk peningkatan rendemen dan efektivitas ekstraksi sudah banyak dilakukan. Balachandran et al. (2006) melakukan ekstraksi berbantu ultrasonik pada jahe yang dapat meningkatkan 30\% rendemen dan mengurangi waktu ekstraksi. (Xia et al., 2006) telah membuktikan bahwa ekstraksi berbantu ultrasonik pada polifenol, asam amino dan kafein dari teh hijau dapat meningkatkan rendemen pada suhu $65{ }^{\circ} \mathrm{C}$. Menurut Chen et al. (2020), membuktikan bawa ekstraksi berbantu ultrasonik pada Cinnamon cassia dapat menigkatkan rendemen sebesar 2,14\% lebih tinggi dibandingkan dengan metode hidrodistilasi yang menghasilkan rendemen sebesar 1,68\%.

Saat ini teknik ekstraksi menggunakan gelombang mikro untuk ekstraksi atsiri bahan hasil pertanian masih tergolong belum sebanyak metode pada umumnya seperti dilusi, maserasi, refluks, dan distilasi. Memanfaatkan kerja dari gelombang ultrasonik yang memungkinkan dalam mendukung peningkatan difusi pelarut dan pelepasan komponen bioaktif di dalam jaringan bawang 
putih. Tujuan penelitian ini adalah investigasi ekstraksi minyak bawang putih lokal dengan teknik ultrasound menggunakan variabel penelitian yang terdiri atas waktu ekstraksi dan varietas bawang putih untuk mengukur kualitas dan kuantitas ekstrak minyak bawang putih.

\section{METODE}

Bahan-bahan yang digunakan dalam penelitian ini yaitu, bawang putih dengan tiga jenis yaitu varietas Bagong, varietas Tunggal dan varietas Sangga yang diperoleh dari Desa Sembalun Kabupaten Lombok Timur. Pelarut ekstraksi ultrasonik menggunakan etanol pro analyst (PA) dengan konsentrasi 90\% (Merck, Jerman), dan akuades. Alat-alat yang digunakan dalam penelitian ini yaitu, ultrasonic cleaning batch (Elmasonic S $300 \mathrm{H}$, Jerman), Rotary vacuum evaporator (Heidolph, Jerman), penangas air, thermo control, gelas beker, pisau, timbangan analitik, botol $10 \mathrm{ml}$, refraktometer, moisture analyzer (Ohaus Moisture Analyzer MB23, USA), pipet tetes, oven, loyang, termometer, erlenmeyer $250 \mathrm{ml}$, gelas beaker ukuran 1 L, sentrifugasi (Dragon LC-04S, Cina), kompor listrik, GC-MS (Shimadzu QP2010, Jepang), stopwatch, saringan, dan pengaduk.

\section{Preparasi Sampel}

Bawang Putih dibersihkan dari kulitnya dan dicincang dengan ukuran $2 \mathrm{~mm}$ sehingga diperoleh bawang putih yang telah menjadi potongan-potongan atau bentuk irisan yang lebih kecil. Irisan bawang putih untuk penelitian ini di timbang seberat $500 \mathrm{~g}$ untuk setiap varietas bawang putih (Bagong, Tunggal, dan Sangga). Selanjutnya, bawang putih di keringkan menggunakan oven pengering suhu $60{ }^{\circ} \mathrm{C}$ selama 6 jam. Pengeringan ke dalam oven bertujuan untuk mengurangi kadar air awal bawang putih supaya keberadaan air di dalam bahan berkurang untuk meningkatkan difusi pelarut ke dalam jaringan umbi bawang putih.

\section{Ekstraksi Bawang Putih dengan Ultrasonik}

Bawang Putih yang telah dikeringkan menggunakan oven, selanjutnya ditimbang sebanyak $20 \mathrm{~g}$ dan dilarutkan ke dalam etanol pro analyst (PA) 90\% dengan volume $100 \mathrm{ml}$ dan di masukkan ke dalam labu ukur. Tahap berikutnya adalah ekstraksi dengan berbantuan ultrasonik yaitu memasukkan air sebanyak $7000 \mathrm{ml}$ ke dalam ultrasonic cleaning bath yang di tunjukkan pada Gambar 1 (Elmasonic S 300 H) frekuensi $37 \mathrm{kHz}$. Labu ukur yang berisi campuran bawang putih dan pelarut etanol di celupkan ke dalam air yang mengisi Elmasonic $S$ $300 \mathrm{H}$. Proses ekstraksi dimulai dengan menghidupkan Elmasonic $S 300 \mathrm{H}$ dengan mengatur lama ekstraksi sesuai perlakuan waktu ekstraksi yaitu 20 menit, 30 menit, dan 45 menit. Perlakuan ekstraksi ini juga berlaku untuk variabel jenis bawang putih lain yang digunakan dalam penelitian ini (Bagong, Tunggal dan Sangga). Hasil ekstrak bawang putih yang terdiri atas padatan dan pelarut (etanol dan minyak bawang putih) disaring dengan menggunakan kasa penyaring untuk memisahkan larutan ekstrak dari padatan kasar bawang putih. Larutan ekstrak kasar bawang putih dimurnikan dengan cara penguapan menggunakan rotary vacum evaporator (Heidolph, Jerman) pada tekanan 175 mBar, 50 rpm dan temperatur $50{ }^{\circ} \mathrm{C}$ selama 60 menit.

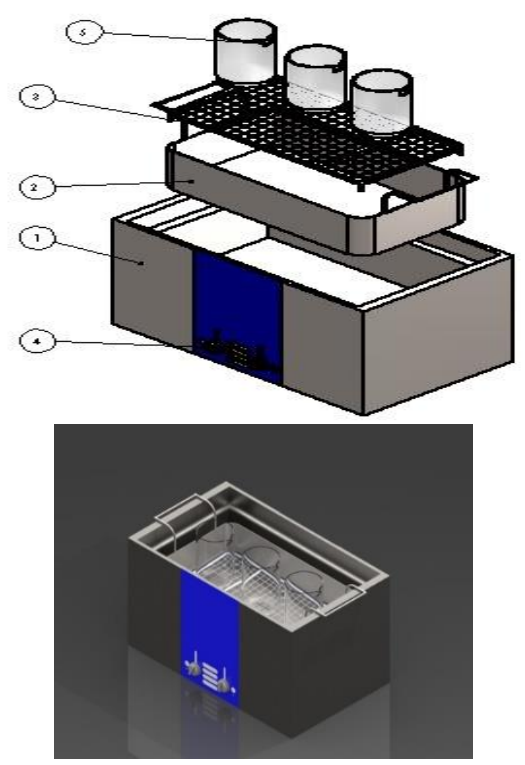

Keterangan:

1. Box sonikator

2. Rak sonikator

3. Rak sonikator

4. Tombol kontrol sonikator

5. Gelas kimia

Gambar 1. Waterbath ultrasonic type ELMASONIC S3OOH 
Pemurnian ekstrak minyak bawang putih Bagong, Tunggal dan Sangga dari padatan terlarut di lakukan dengan cara memasukkan ekstrak kasar ke dalam tabung yang berada di dalam sentrifus (Dragon, LS-04, Cina). Ekstrak bawang putih disentrifus dengan kecepatan 3000 rpm dalam waktu 15 menit hingga didapatkan minyak bawang putih yang terbebas dari zat pengotor, setelah itu minyak atsiri disimpan pada suhu ruang dan tempat gelap sebelum dilakukan analisis parameter lanjutan. Proses ekstraksi dan analisis dalam penelitian ini di lakukan pengulangan sebanyak tiga kali.

\section{Rendemen Ekstrak}

Ekstrak pekat hasil evaporasi yang dihasilkan, ditimbang dalam wadah yang telah diketahui beratnya kemudian berat ekstrak pekat dibandingkan dengan berat awal bubuk (Handayani et al., 2016). Langkah-langkah dalam pengukuran rendemen sebagai berikut:

a. Ditimbang berat awal Bawang Putih kering sebagai nilai A.

b. Disiapkan botol $10 \mathrm{ml}$ dan jarum suntik 5 $\mathrm{ml}$

c. Diambil sampel minyak menggunakan suntikan kemudian ditimbang berat minyak Bawang Putih, dicatat beratnya sebagai nilai $B$.

d. Data hasil pengamatan kemudian dihitung menggunakan Persamaan 1.

Rendemen $(\%)=\frac{B}{A} \times 100 \%$

keterangan: $\quad A=$ Berat awal bahan

$\mathrm{B}=$ Berat akhir bahan

\section{Indeks Bias}

Indeks bias suatu zat merupakan ukuran kelajuan kecepatan udara di dalam zat cair dibanding ketika di udara (Apriyanto et al., 2013). Indeks bias digunakan untuk pengujian kemurnian minyak. Indeks bias akan meningkat pada minyak yang memiliki komponen penyusun dengan rantai karbon panjang dan juga terdapat sejumlah ikatan rangkap atau komponen oksigen ikut tersuling (Rusdiana, 2015). Semakin tinggi indeks bias menunjukkan minyak memiliki kualitas yang baik.

Pengukuran indeks bias menggunakan refraktometer. Langkah-langkah pengukuran indeks bias sebagai berikut: a. Diambil sampel minyak Bawang Putih secukupnya, kemudian diteteskan pada prisma refraktometer, biarkan 1-2 menit untuk mencapai temperatur $25^{\circ} \mathrm{C}$.

b. Dibaca indeks biasnya dengan menekan tombol start pembacaan pada refraktometer.

c. Setelah selesai, prisma dibersihkan menggunakan air dan tisu sampai kering.

Diulangi langkah a sampai c untuk setiap sampel minyak Bawang Putih yang diuji.

\section{Aktivitas Antioksidan (AA) \\ Sampel sebanyak $1 \mathrm{ml}$ ditambahkan dengan larutan dpph $(0,1 \mathrm{mM})$ dan metanol yang sudah tercampur sebelumnya sebanyak 4 $\mathrm{ml}$, kemudian divorteks selama 1 menit untuk melarutkan sampel dalam larutan DPPH dan metanol yang sudah tercampur. Setelah divorteks, didiamkan di tempat gelap selama 30 menit. Kemudian diukur absorbansinya pada panjang gelombang $517 \mathrm{~nm}$ dengan spektrofotometer (Yuniarto et al., 2019). Aktivitas antioksidan dapat dihitung dengan menggunakan Persamaan (2).}

$\mathrm{AA}(\%)=\frac{\text { Abs kontrol-Abs sampel }}{\text { Abs kontrol }} \times 100 \%$

Keterangan:

Abs Kontrol: Nilai serapan (Abs) larutan kontrol pada panjang gelombang optimum.

Abs Sampel: Nilai serapan (Abs) larutan uji atau larutan pembanding pada panjang gelombang optimum.

\section{Gas Chromatography-Mass Spestroscopy}

Analisis GC-MS minyak bawang putih dianalisis menggunakan Shimadzu QP 5000. Prosedur analisis bioaktif minyak bawang putih dengan cara menyiapkan sampel minyak bawang putih sebanyak $1 \mu \mathrm{L}$ dan diinjeksikan ke GC-MS melalui kolom kaca dengan dimensi panjang $25 \mathrm{~cm}$ dan diameter $0,25 \mathrm{~mm}$ dengan fasa diam CP-Sil 5CB dengan temperatur oven diprogram antara $70-270 \quad{ }^{\circ} \mathrm{C}$ dengan laju kenaikan temperatur $10{ }^{\circ} \mathrm{C} /$ menit, gas pembawa Helium bertekanan $12 \mathrm{kPa}$, total laju $30 \mathrm{~m} \mathrm{~L} /$ menit dan split ratio sebesar 1:50. 


\section{HASIL DAN PEMBAHASAN}

\section{Rendemen Minyak Bawang Putih}

Nilai rendemen merupakan parameter yang memberikan pengaruh signifikan terhadap variabel ekstraksi yang telah diterapkan. Hasil penghitungan rendemen bawang putih dengan teknik ekstraksi ultrasonik berkisar antara 2,83\% sampai $12,35 \%$. Nilai rendemen berdasarkan jenis bawang putih dan lama ekstraksi di tunjukkan pada Gambar 2.

Varietas bawang putih Sangga menghasilkan rendemen ekstrak minyak lebih tinggi secara konsisten untuk setiap perlakuan waktu ektraksi yang digunakan apabila dibandingkan dengan jenis bawang putih varietas Bagong dan Tunggal. Berdasarkan hasil pengukuran, rendemen minyak bawang putih Tunggal terekstrak paling rendah sebesar $2,83 \%$ untuk perlakuan lama ekstraksi 20 menit. Nilai ini lebih tinggi dibandingkan dari bawang putih tunggal yang diekstrak dengan metode dilusi menggunakan etanol 96\% sebesar 1,67\% (Adhuri et al., 2018).

Laporan spesifik tentang rendemen minyak bawang putih varietas lokal (Tunggal, Bagong, Sangga) yang terkestrak dengan ultrasonik masih sangat terbatas data ilmiahnya. Namun, menggunakan pembanding metode lain dan jenis bawang lain diperoleh data ilmiah rendemen ekstrak bawang putih sebesar 0,7\% yang diekstrak menggunakan metode microwave-assisted hydrodistillation dalam pelarut campuran air dan etanol (1:1,5) (Aing, 2017). Jenis bawang Dayak yang diekstrak menggunakan metode refluks dan pelarut metanol menghasilkan rendemen $1,99 \%$.

Waktu ekstraksi adalah salah satu faktor terhadap hasil ekstrak yang diinginkan. Selama proses UAE akan terjadi kontak antara zat terlarut dengan bahan pelarut. Terjadinya ekstraksi antara zat terlarut dengan pelarut selama UAE mengikuti dua tahap yaitu: 1) washing atau terlarutnya komponen pada bagian permukaan yang berjalan pada periode 10-20 menit dan 2) slow extraction terjadi difusi pelarut yang diikuti dengan perpindahan massa zat terlarut ke dalam pelarut yang umumnya ditemui pada periode 60-100 menit. Fenomena ini juga sejalan dengan hasil temuan bahwa rendemen ekstrak minyak bawang putih varietas lokal yang digunakan dalam penelitian ini mengalami peningkatan cukup besar dengan waktu ekstraksi dimana periode ekstraksi 45 menit mengalami kenaikan hasil ekstrak yang cukup besar. Hasil uji statistik menggunakan SPSS menunjukkan bahwa nilai signifikansi dari perlakuan jenis bawang dan waktu memiliki nilai signifikansi sebesar 0,374 dan 0,967 yang identik dengan perbedaan sangat nyata kedua variabel tersebut terhadap rendemen minyak bawang putih.

Peningkatan nilai rendemen minyak bawang putih dengan metode ekstraksi ultrasonik juga erat kaitannya dengan fenomena kavitasi yaitu getaran-getaran yang timbul menyebabkan kerusakan jaringan di dalam irisan bawang putih.

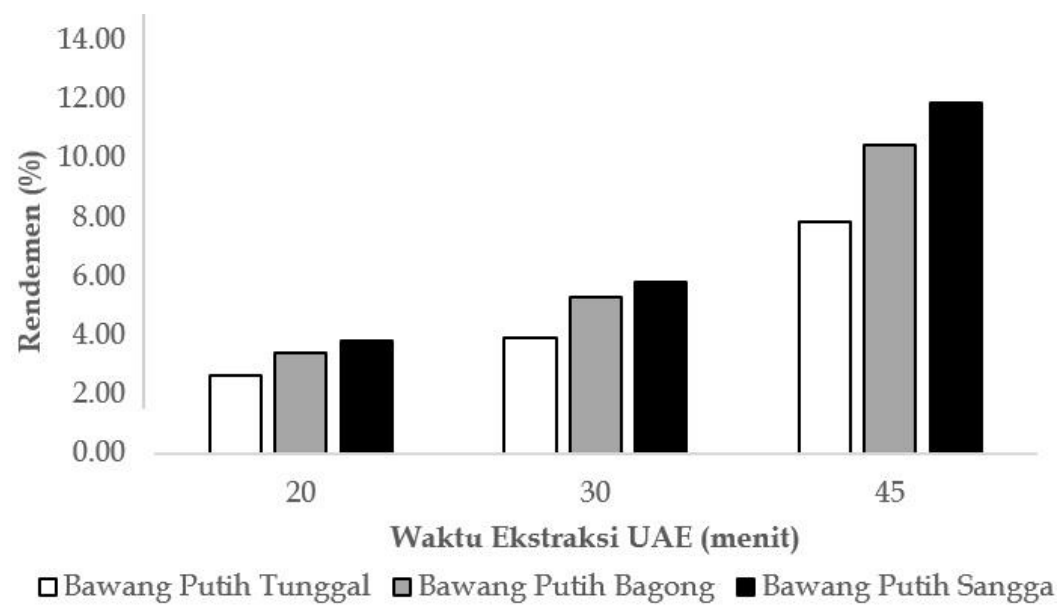

Gambar 2. Rendemen minyak bawang putih terekstrak dengan metode ultrasonik $37 \mathrm{kHz}$ 


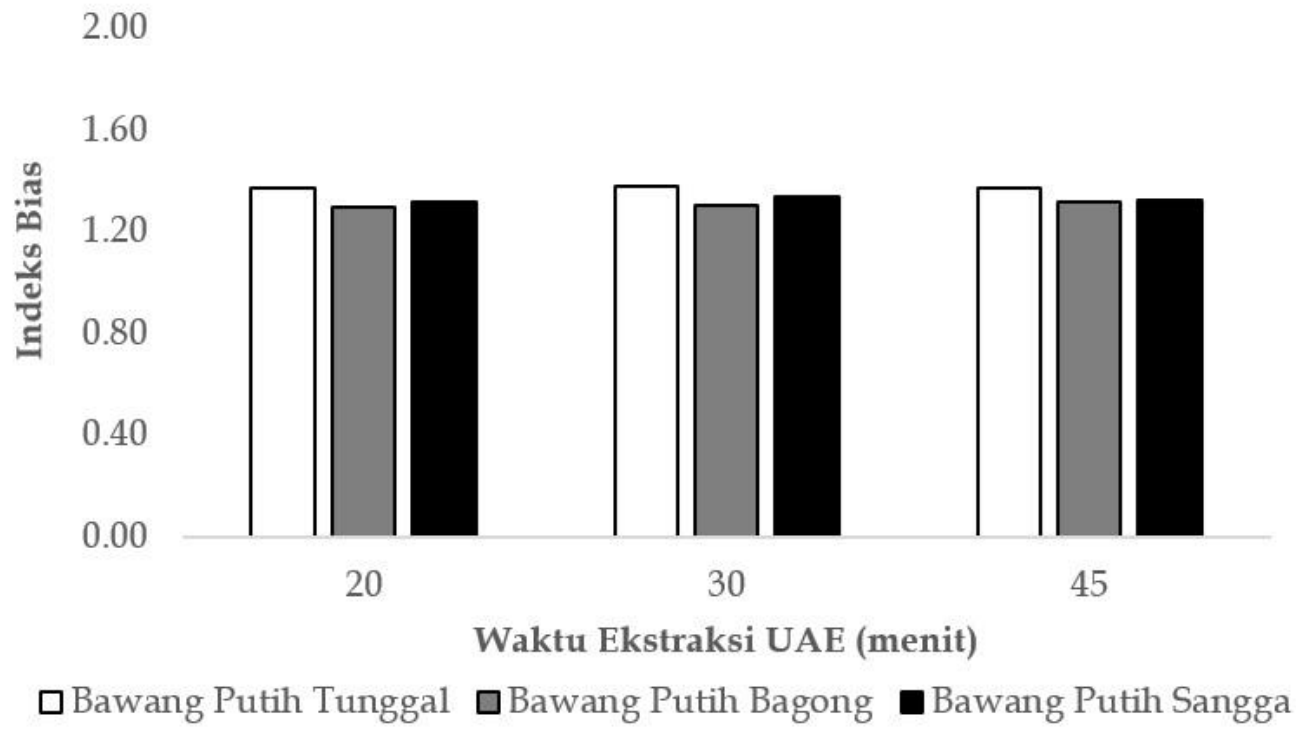

Gambar 3. Permeabilitas oksigen kemasan aktif PLA-PEG400-BHT fungsi suhu

Selanjutnya, kavitasi ultrasonik juga berdampak kepada peningkatan pecahnya gelembung akibat adanya kenaikan tekanan sehingga membantu proses difusi pelarut ke dalam jaringan yang berisi minyak bawang putih. Hasil observasi selama ekstrak bawang putih varietas lokal menunjukkan pembentukan gelembung semakin besar sejalan dengan lama waktu ultrasonikasi. Selanjutnya, gelembung-gelembung pecah akan diikuti dengan penampakan perubahan warna di dalam pelarut. Hal ini identik dengan fenomena transfer massa zat terlarut semakin banyak. Setelah dilakukan pengukuran, volume rendemen ekstrak minyak bawang putih lebih tinggi dengan perlakuan lama periode ekstraksi. Perlakuan waktu ekstraksi yang semakin panjang akan meningkatkan energi ultrasonik dan memperbesar terjadinya kavitasi akustik disekitar bahan. Pembentukan kavitasi akustik ini berperan dalam proses ektraksi akan menyebabkan pelebaran pori yang akan membantu pelarut untuk berdifusi ke jaringan sel (Mason et al., 2015). Ciri khas dari kavitasi adalah munculnya gelembung-gelembung kecil dan ledakan gelembung besar sehingga akan menghasilkan tekanan yang lebih tinggi untuk terdorong ke bagian dalam jaringan yang memiliki tekanan lebih rendah (Chandrapala et al., 2012).

\section{Indeks bias}

Indeks bias digunakan untuk pengujian kemurnian minyak. Indeks bias akan meningkat pada minyak yang memiliki komponen penyusun dengan rantai karbon panjang dan juga terdapat sejumlah ikatan rangkap atau komponen oksigen ikut tersuling (Rusdiana, 2015). Berdasarkan Gambar 3, nilai indeks yang ekstrak bawang putih untuk variabel jenis bawang dan waktu ekstraksi diperoleh berkisar antara 1,3678-1,3741. Nilai indeks bias minyak bawang putih yang dihasilkan dari proses ekstraksi ultrasonik untuk varibel jenis bawang dan waktu ekstraksi tidak berbeda jauh yang mengindikasikan bahwa tingkat kemurnian minyak bawang putih relatif sama hasilnya. Uji lanjutan data pengukuran nilai indeks bias dengan SPSS diperoleh nilai signifikansi pengaruh lama waktu ekstraksi sebesar 0,097 atau lebih besar dari nilai signifikansi sebesar 0,05 . Hal ini menunjukkan bahwa variabel lama ekstraksi bawang putih tidak memberikan perbedaan terhadap parameter nilai indeksi bias yang dihasilkan. Hubungan waktu dan jenis bawang dilakukan uji menghasilkan nilai signifikansi sebesar 0,078 yang menunjukkan bahwa interaksi diantara varietas bawang dan lama ekstraksi tidak cukup menyebabkan perbedaan parameter mutu indeks bias minyak bawang putih 
varietas lokal yang digunakan dalam penelitian ini

Nilai indeks bias minyak bawang putih Tunggal berkisar antara 1,3699-1,3678; bawang putih Bagong indeks bias didapatkan berkisar 1,3689-1,3692; dan bawang putih Sangga indeks bias didapatkan berkisar 1,3711-1,3678 dengan waktu ekstraksi selama 20 menit sampai 45 menit. Membandingkan hasil dari peneliti lain terhadap parameter nilai indeks bias, Rafe dan Mohsen (2014) melaporkan bahwa indeks bias bawang putih dengan metode ekstraksi pelarut didapatkan hasil sebesar 1,4334, indeks bias bawang putih dengan menggunakan metode distilasi uap didapatkan hasil sebesar 1,4334 sedangkan dengan menggunakan metode SFC$\mathrm{CO}$ atau ekstraksi superkritis fluida didapatkan hasil sebesar 1,4344. Ada beberapa faktor yang dapat mempengaruhi perbedaan nilai indeks bias seperti temperatur dan kekentalan zat cair.

\section{Gas Chromatography and Mass Spectroscopy}

Gas Chromatography and Mass Spectroscopy (GCMS) salah satu parameter penting untuk mengukur jenis dan kandungan senyawa dalam sampel baik secara kualitatif maupun kuantitatif. Kandungan senyawa pada minyak bawang putih yang diekstrak menggunakan UAE dalam penelitian ini terdeteksi sebanyak 37 komponen. Di-2propenyl (CAS), acetate (CAS), 1- acetate (CAS), di-2- propenyl (CAS) Allyl trisufide, Hexadecanoic acid (CAS) Palmitic acid, Carbonik acid, Octadecanoic acid (CAS) Stearic acid, Dodecanoic acid, Hexadecanoic acid (CAS) Palmitic acid, Enoic acid, Dodecanoic acid, Dodecanoic acid, acetate (CAS), 1- acetate (CAS), di-2-propenyl (CAS) Allyl trisulfide, Hexadecanoic acid (CAS) Palmitic acid, Enoic Acid, Dodecanoic acid, Carbonic acid Dodecanoic acid, di-2- propenyl (CAS), di-2propenyl (CAS) Allyl trisulfide, Hexadecanoic acid (CAS) Palmitic acid, Enoic acid, Octadecanoic acid (CAS) Stearic acid, Dodecanoic acid, Dodecanoic acid, di-2- propenyl (CAS) Allyl trisulfide, Cytidine (CAS) Cyd, Hexadecanoic acid (CAS) Palmitic acid, Carbonic acid, Octadecanoic acid (CAS) Stearic acid, 2-Propenoic acid, Dodecanoic acid, Hexadecanoic acid (CAS) Palmitic acid, Carbonic acid-(1).

Komponen atsiri dari bawang putih identik dengan kandungan sulfur yang terwakili oleh gugus allyl trisulfide. Kandungan allyl trisulfide bawang putih dari berbagai varietas dari China, India, Spanyol, Serbia,
Tunisia dan Yunani berkisar antara 7,9-13,2\% (Satyal et al., 2017). Berdasarkan hasil pengukuran dengan GCMS, ekstrak minyak bawang putih dengan UAE pada frekuensi 37 $\mathrm{kHz}$ memiliki konsentrasi allyl trisulfide diperoleh sebesar 11,19\% untuk jenis bawang putih Tunggal, sedangkan jenis Bagong sebesar 5,26\%, dan jenis Sangga 3,00\%.

Pada penelitian yang telah dilakukan oleh Pratama (2018) berupa minyak umbi bawang putih (Allium sativum L) diisolasi dengan metode hidrodistilasi menggunakan alat stahl. Umbi Bawang Putih didistilasi selama 4-5 jam menghasilkan minyak sebanyak $0,05 \%$ (b/b). Komponen kimia minyak asiri umbi Bawang Putih dianalisis menggunakan GC-MS menunjukkan terdapat 11 komponen dengan komponen utama yaitu metil allil trisulfida $(4,84 \%)$.

\section{Aktivitas Antioksidan}

Metode DPPH adalah metode yang dapat digunakan untuk menentukan aktivitas antioksidan dalam sampel yang akan diujikan dengan melihat kemampuannya dalam menangkal radikal bebas. Aktivitas antiksidan minyak bawang putih (Tunggal, Bagong dan Sangga) yang diperoleh dari ekstraksi ultrsonik ditunjukkan pada Tabel 1.

Tabel 1. Nilai Aktivitas Antioksidan Minyak Bawang Putih

\begin{tabular}{lrrc}
\hline \multirow{2}{*}{ Bawang Putih } & \multicolumn{3}{c}{ Waktu (Menit) } \\
\cline { 2 - 4 } & 20 & \multicolumn{1}{c}{30} & \multicolumn{1}{c}{45} \\
\hline Tunggal (\%) & 0,77 & 9,90 & 20,47 \\
Bagong (\%) & 1,28 & 14,21 & 39,66 \\
Sangga (\%) & 11,13 & 34,38 & 42,84 \\
\hline
\end{tabular}

Komponen antioksidan yang dimiliki oleh minyak bawang putih adalah alisin, alin, alil sistein dan alil disulfida (Lawrence et al., 2011). Berdasarkan Tabel 1, di atas bahwa aktivitas antioksidan dari ketiga jenis Bawang Putih sangat jauh berbeda berkisar 0,77-42,84\% untuk semua sampel. Dapat dilihat bahwa nilai aktivitas antioksidan yang didapatkan bawang putih Tunggal berkisar antara 0,7720,47\% dengan waktu ekstraksi selama 20 menit sampai 30 menit. Pada bawang putih Bagong nilai aktivitas antioksidan yang didapatkan berkisar antara 1,28-39,67\% dengan waktu ekstraksi selama 20 menit 
sampai 30 menit. Pada bawang putih Sangga nilai aktivitas antioksidan yang didapatkan berkisar antara $11,13-42,84 \%$ dengan waktu ekstraksi selama 20 menit sampai 30 menit. Nilai aktivitas antioksidan yang paling tinggi yaitu pada bawang putih Sangga berkisar antara $42,84 \%$ dengan waktu ekstraksi selama 45 menit, sedangkan nilai aktivitas antioksidan yang paling rendah yaitu pada bawang putih Tunggal berkisar antara $0,77 \%$ dengan waktu ekstraksi selama 20 menit.

Nilai aktivitas antioksidan dari ekstrak minyak bawang putih secara konsisten semakin tinggi dengan waktu ekstraksi yang lebih panjang. Peneliti lain melaporkan, penggunaan metode maserasi dalam proses ekstraksi bawang putih tunggal berbantuan pelarut etanol menghasilkan ekstrak bawang putih dengan kandungan aktivitas antioksidan 10,61\% (Prasonto et al., 2017). Selain itu, Hexadea (2018) melaporkan bahwa penentuan kondisi umum terhadap kandungan antioksidan dengan metode DPPH dalam tiga jenis bawang putih menggunakan ekstraksi ultrasonik dengan frekuensi sebesar $35 \mathrm{kHz}$ didapatkan pada $20 \mathrm{ml}$ pelarut aquades, berat sampel $3 \mathrm{~g}$ dan waktu ekstraksi 60 menit. Kandungan didapatkan pada bawang putih lokal, impor, dan tunggal berturut-turut yaitu $1,3595 \mathrm{mg} / \mathrm{g}, 2,3344 \mathrm{mg} / \mathrm{g}$, dan 3,7991 mg/g. kandungan antioksidan tertinggi diperoleh dalam ekstraksi Bawang Putih Tunggal dengan ultrasonik dibandingkan maserasi.

Penelitian yang telah dilakukan oleh Isrianto dan Tania (2018) bahwa hasil uji antioksidan pada ekstrak kombinasi Dlingu dan bawang putih Jantan (Tunggal) dengan pelarut etanol $70 \%$ menggunakan metode maserasi selama 1×24 jam dan difiltrat yang diperoleh dengan menggunakan rotary vacuum evaporator selama 24 jam menghasilkan aktivitas antioksidan yang sangat kuat sebanyak $17.062 \mathrm{mg} / \mathrm{ml}$.

Penelitian yang telah dilakukan oleh Pratama (2018) bahwa Minyak atsiri umbi bawang putih dilakukan uji aktivitas antioksidan dengan metode DPPH (2,2diphenyl-1-picrylhydrazyl) sebagai radikal bebas untuk memperoleh nilai $\mathrm{IC}_{50}$ (Inhibitor Concentration) dilakukan pengamatan dengan menggunakan spektrofotometer UV-Visible pada panjang gelombang maksimum $517 \mathrm{~nm}$ menunjukkan nilai $\mathrm{IC}_{50}$ sebesar $22,863 \mathrm{mg} / \mathrm{L}$ merupakan golongan antioksidan sangat kuat.
Berdasarkan hasil penelitian diketahui bahwa bawang putih (Allium sativum) memiliki daya aktivitas antioksidan. Seluruh varietas bawang putih yang dijadikan sampel pada penelitian ini memiliki daya aktivitas antioksi dan termasuk klasifikasi aktivitas antioksidan varietas bawang putih Tunggal, Bagong dan Sangga memiliki daya aktivitas antioksidan yang lebih baik. Nilai rendemen tertinggi pada pengujian ini didapatkan pada perlakuan bawang putih Sangga dengan waktu ekstraksi 45 menit yaitu sebesar 12,35\%. Kemudian nilai rendemen terendah didapatkan pada perlakuan bawang putih Tunggal dengan waktu ekstraksi 20 menit yaitu sebesar $2,83 \%$.

\section{SIMPULAN}

Ekstraksi berbantuan gelombang ultrasonik untuk produksi minyak esensial bawang putih varietas lokal dengan variasi waktu 20, 30, dan 40 menit di dalam pelarut etanol $90 \%$ pada frekuensi $37 \mathrm{kHz}$ menghasilkan rendemen lebih tinggi pada jenis bawang Sangga dibandingkan jenis Tunggal dan Bagong. Nilai rendemen minyak bawang putih sebesar $12,35 \%$. Perlakuan waktu tidak memberikan hasil yang berbeda terhadap parameter indeks bias dengan nilai indeks bias antara antara 1,3678-1,3741. Hasil investigasi dengan GC-MS jumlah komponen aktif sebanyak 37 jenis deimana senyawa allyl trisulfide yang menjadi ciri khas bioaktif bawang putih paling tinggi pada jenis bawang putih Tunggal sebesar $11,19 \%$. Aktivitas antioksidan minyak esensial bawang putih meningkat dengan bertambahnya waktu ekstraksi untuk semua jenis bawang yang digunakan.

\section{UCAPAN TERIMA KASIH}

Penelitian ini terlaksana atas dukungan dari Keyworks Laboratory, Gunungsari, Lombok Barat.

\section{DAFTAR PUSTAKA}

Adhuri, I, -K., Kristina T, -N., Antari, A, -L., 2018. Perbedaan potensi antibakteri 
bawang putih tunggal dengan bawang putih majemuk terhadap salmonella typhi. Diponegoro Medical Journal (Jurnal Kedokteran Diponegoro). 7, 415-423. https://doi.org/10.14710/dmj.v7i2.20670

Aing, IYS. 2017 Microwave-Assisted Hydrodistillation: Garlic Essential Oil Recovery. Curtin University. Australia

Apriyanto, D, -K., Pauzi, G, -A., Warsito., 2013. Pemanfaatan hukum snellius sebagai dasar alat ukur indek bias dan viskositas larutan garam berbasis mikrokontroler avr atmega8535. Jurnal Teori dan Aplikasi Fisika. 1, 1-6. http://dx.doi.org/10.23960\%2Fjtaf.v1i1. 467

Balachandran, -S., Kentish, S, -E., Mawson, -R., Ashokkumar, -M., 2006. Ultrasonic enhancement of the supercritical extraction from ginger. Ultrasonics Sonochemistry. 13, 471-479. https://doi.org/10.1016/j.ultsonch.2005 .11 .006

Chandrapala, -J., Oliver, -C., Kentish, -S., Ashoukkumar, -M., 2012. Ultrasonics in food processing. Ultrasonics Sonochemistry. 19(5), 975-983. https://doi.org/10.1016/j.ultsonch.2012 .01 .010

Chen, -G., Sun, -F., Wang, -S., Wang, -W., Dong, -J., Gao, F., 2020. Enhanced extraction of essential oil from Cinnamomum cassia bark by ultrasound assisted hydrodistillation. Chinese Journal of Chemical Engineering. 36, 38-46. https://doi.org/10.1016/j.cjche.2020.08. 007

Cravotto, -G., Cintas, -P., 2006. Power ultrasound in organic synthesis: Moving cavitational chemistry from academia to innovative and large-scale applications. Chemical Society Reviews. 35, 180-196. https://doi.org/10.1039/b503848k

Handayani, -H., Siherfyna, F, -H., Yunianta. 2016. Ekstraksi antioksidan daun sirsak metode ultrasonik bath (kajian rasio bahan : Pelarut dan lama ekstraksi). Jurnal Pangan dan Agroindustri. 4, 1- 11.

Hexadea, F, D, -D. 2018. Optimasi Ekstraksi Antioksidan Total dalam Bawang Putih (Allium sativum) dengan Bantuan Gelombang Utrasonik dan Penentuan Kadarnya dengan Metode DPPH.
Skripsi. Universitas Andalas. Padang.

Isrianto, P, -L., Tania P, O, A., 2018. Antioxidant activity in combination extract of acorus calamus l. (dlingu) and Allium sativum (Garlic). International Journal of Applied Biology. 3, 1 - 7. https://doi.org/10.20956/ijab.v3i1.5471

Hoffmann, M, -R., Hua, -I., Höchemer, -R., 1996. Application of ultrasonic irradiation for the degradation of chemical contaminants in water. Ultrasonics Sonochemistry. 3, 163-172 https://doi.org/10.1016/S13504177(96)00022-3

Kobus, -Z., Kusinska, -E., 2008. Influence of physical properties of liquid on acoustic power of ultrasonic processor. TEKA Kom. Mot. Energy Roln. 8a, 71-78.

Löning, J, -M., Horst, -C., Hoffmann, -U., 2002. Investigations on the energy conversion in sonochemical processes. Ultrasonics Sonochemistry. 9, 169-179. https://doi.org/10.1016/S13504177(01)00113-4

Mason, T, -J., Chemat, -F., Ashokkumar, -M., 2015. Power ultrasonics for food processing. Power Ultrasonics: Applications of High-Intensity Ultrasound. 815-843. https://doi.org/10.1016/B9781-78242-028-6.00027-2

Pratama, D, A. 2018. Isolasi dan Analisis Komponen Kimia Minyak Atsiri Umbi Bawang Putih (Allium sativum L) Serta uji Aktivitas Antibakteri dan Antioksidan. Skripsi. Universitas Sumatera Utara. Medan.

Prasonto, -D., Riyanti, -E. dan Gartika, M. 2017. Uji aktivitas antioksidan ekstrak bawang putih (Allium sativum). ODONTO Dental Journal. 4, 122 - 128. http://dx.doi.org/10.30659/odj.4.2.122128

Rusdiana, R. 2015. Analisis Kualitas Minyak Goreng Berdasarkan Parameter Viskositas dan Indeks Bias. Skripsi Fakultas Sains dan Teknologi Universitas Islam Negeri Walisongo. Semarang.

Rafe, -A. Nadjafi, M, -A., 2014. Physicochemical characteristics of garlic (Allium sativum L.) oil: effect of extraction procedur. International Journal of Nutrition and Food Sciences. 3, 1-5. 
Jurnal Teknologi Pertanian Vol. 22 No. 3 [Desember 2021] 177-186

Aplikasi Ultrasound Assisted Extraction untuk Produksi Minyak Bawang Putih Varietas Lokal [Yuniarto dkk]

https://doi.org/10.11648/j.ijnfs.s.20140 30601.11

Satyal, -P., Craft, J, -D., Sosoky, N, -S., Setzer $\mathrm{W},-\mathrm{N} ., 2$ 2017. The chemical compositions of the volatile oils of garlic (Allium sativum) and wild garlic (Allium vineale). Foods. 6 , 63. https:// doi.org/10.3390/foods6080063

Sholihah, -M., Ahmad, -U., Budiastra, I, -W., 2017. Aplikasi gelombang ultrasonik untuk meningkatkan rendemen ekstraksi dan efektivitas antioksidan kulit manggis. Jurnal Keteknikan Pertanian. 5, $161 \quad-\quad 168$. https://doi.org/10.19028/jtep.05.2.\%25p

Son, -Y., Lim, -M., Khim, -J., Kim, -L., Ashokkumar, M., 2012. Comparison of calorimetric energy and cavitation energy for the removal of bisphenol-A: The effects of frequency and liquid height. Chemical Engineering Journal. 183, 3945. https://doi.org/10.1016/j.cej.2011.12.016

Sulaswatty, A. 2019. Penerapan Teknologi Nonkonvensional dalam Ekstraksi Komponen Utama Atsiri dan Produk Turunannya di Indonesia. LIPI Press, Jakarta
Tiwari, B, -K., 2015. Ultrasound: A clean, green extraction technology. TrAC - Trends in Analytical Chemistry. 71, 100-109. https://doi.org/10.1016/j.trac.2015.04.0 13

Wagh, -A., Birkin, -P., Martini, -S., 2016. Highintensity ultrasound to improve physical and functional properties of lipids. Annual Review of Food Science and Technology. 7, 23-41. https://doi.org/10.1146/annurev-food041715-033112

Xia, -T., Shi, -S., Wan, X., 2006. Impact of ultrasonic-assisted extraction on the chemical and sensory quality of tea infusion. Journal of Food Engineering. 74, 557-560.

https://doi.org/10.1016/j.jfoodeng.2005 .03 .043

Yuniarto, -K., Purwanto, -S., Welt, B, -A., Lastriyanto, -A., 2019. Ascorbic acid degradation in cut lemon packaged using oxygen scavenging active film during storage. Makara Journal of Technology. 22, 129-134. https://doi.org/10.7454/mst.v22i3.3659 